\title{
THE AVAILABILITY OF FIREARMS AND LEVELS OF HOMICIDE AND SUICIDE PERPETRATED WITH THEIR USE
}

\begin{abstract}
The paper reviews the literature with a view to answering the question as to whether the easier availability of firearms affects the level of homicides and suicides with their use. The author compared Polish and other similar laws where the access to firearms is strictly regulated, as against systems where the availability of firearms is facilitated, either owing to liberal laws (Colombia, Brazil, Switzerland) or to Constitutional guarantees (USA, Mexico). The comparison revealed a correlation between the availability of firearms and levels of homicide and suicide by firearms.
\end{abstract}

\section{Keywords:}

firearms - firearms law - homicide - suicide

\section{INTRODUCTION}

A great many academics, but not just academics, pose the question of whether the facilitated access to firearms is reflected in the level of crime with firearms, and in particular whether it has a clear impact on the level of homicides and suicides with firearms. The author of this article

* Leszek Stępka, Assistant Professor, Department of Criminal Proceedings and Criminalistics, Nicolaus Copernicus University in Toruń; ORCID: 0000-0002-2589-654X; e-mail: lstepka@umk.pl. 
undertook a closer look at the availability of firearms in selected countries of the world with varying models of firearms availability to individuals, and the levels of homicide and suicide by firearms in these countries.

The availability of firearms to individuals is regulated by law in most countries. However, the various legal systems vary, and not only in detail, but also reflect different 'philosophies' on the issue of citizens' access to firearms. There are liberal measures, recognising that owning a gun is, as it were, a civil right, allowing, with natural restrictions on certain groups of people, types of weapons, and weapons with certain characteristics, unfettered access to firearms (United States - USA). Finland also had similar legislation. It was only after the Tuusula High School massacre on 12 November 2007 that amendments were made to tighten the rules on gun ownership (2008). Other legislation allows the acquisition and possession of weapons after prior authorization by the relevant state authorities (Czech Republic, France, Italy, United Kingdom, Spain, Russia, Lithuania). In Germany, a permit is granted on the indication of a specifically justified reason. In other European countries, however, such a permit is granted unless there are negative conditions laid down by law.

On the other end of the spectrum from the US is Japan, where a complete ban exists on the possession of firearms for personal protection by individuals. Weapons are possessed only by the military, police, and some government services. Of course, there are exceptions, as for hunting and for sporting purposes, weapons can be possessed with the approval of the Public Safety Commission of the relevant prefecture. No permit can be issued to persons under 18 years of age, or to those who are mentally unbalanced, drug addicts, without a fixed residence or with a criminal record, which is the same as in most countries in the world. The permit must be renewed every three years. Any toy imitating a weapon must be brightly coloured. If you wish to own a white weapon, a permit must be obtained for the purpose of collecting antique weapons. Strict controls are carried out and smuggling is combated. Illegal possession of weapons is punishable by up to 10 years in prison. ${ }^{1}$

${ }^{1}$ B. Hołyst, Japonia - przestępczość na marginesie cywilizacji [Japan - Crime on the Margins of Civilisation], Wydawnictwo Prawnicze, 1994, p. 231; J. Izydorczyk, Hanzai znaczy przestępstwo: ściganie przestępstw pospolitych i white-collar-crimes w Japonii [Hanzai Means 
In the United Kingdom, the Firearms Act, ${ }^{2}$ which was amended in 1997, makes the right to possess arms and ammunition conditional on obtaining an appropriate permit and strict compliance with its conditions.

The problem of the availability of firearms to individuals has also been addressed by the United Nations (UN). The Fifth Session of the UN Commission on Crime Prevention and Justice, held in Vienna from 21 to 31 May 1996, produced a report, 'Measures To Regulate Firearms', which recommended further research to increase controls on the manufacture and trade of firearms.

M. Filar, ${ }^{3}$ on the basis of the above-mentioned report of the UN Secretary General, has divided the applied legal solutions in individual states into four groups:

1. Legal systems that allow the acquisition and possession of firearms by citizens with prior registration - the registration model. In this case, the role of the state authorities is limited only to registering the acquired weapons. Naturally, not everyone can buy a weapon. Restrictions apply to people with mental disorders and previous criminal records. Also, not every type of weapon is available. Usually it is not possible to buy and register automatic weapons. An example of countries where such a model of access to weapons has been adopted is the USA.

2. Legislation that allows the acquisition and possession of firearms by citizens with prior authorization (usually from the police authorities) - the legal licensing model. The permit is issued upon fulfilment of general conditions laid down by law. For instance, Norway is a country with such a solution (a permit is issued after a minimum of six months' membership of a shooting club and passing an examination on safety rules and weapon han-

Crime: Prosecuting Common and White-Collar Crimes in Japan], Wolters Kluwer Polska, 2008, p. 144.

2 J. B. Hill, Weapons Law, Sweet \& Maxwell Ltd., 1989, p. 6 et seq.

${ }^{3}$ M. Filar, Prawo posiadania broni palnej jako obywatelskie prawo podmiotowe [The Right to Possession of Firearms as a Subjective Civil Right], in Teoria prawa, filozofia prawa, wspótczesne prawo i prawoznawstwo [Theory of Law, Philosophy of Law, Modern Law and Jurisprudence], Publ. UMK, 1998, p. 64. 
dling skills). Argentina, Austria, and Switzerland have similar regulations governing the availability of firearms.

3. Opportunistic rationing model. Under this system it is lawful to acquire and possession of firearms by citizens after obtaining a permit from the state authorities (usually the police) after the applicant for such a permit presents a particularly justified reason for such possession - e.g. an above-average state of danger. Examples of countries that apply this model are Sweden, Germany, and Poland.

The last, but also the least used system of arms rationing, is the restrictive model. In countries applying this system of arms availability (e.g. Japan), it is practically unfeasible for citizens to legally own firearms, except for hunting and sporting weapons.

This article aims to examine whether the facilitated availability of firearms to individuals affects homicide and suicide levels committed with firearms.

The crime of homicide is one of the most serious crimes in all legal systems. In contrast, suicide is one of the most serious social problems in every country in the world.

The Polish penal codes of 1932 and 1969 did not distinguish between qualified types of homicide. A homicide committed with a firearm was treated in the same way as a homicide with another instrument (knife, axe, etc.) or without the use of any instrument (force of blows, poison. ${ }^{4}$

The 1997 Penal Code originally provides in Section 2 of Article 148 for qualified types of murder: 1) with particular cruelty; 2) in connection with taking a hostage, rape, or robbery; 3 ) as a result of motivation deserving particular condemnation; 4) with the use of firearms or explosives. Qualified types of homicide are punishable by a higher penalty - from 12 years of imprisonment (in the basic type the lower penalty limit is 8 years of imprisonment). While the first three qualified types do not raise major controversies, this is no longer the case with murder with a firearm. A. Marek points out that it does not matter what tool

${ }^{4}$ J. Bafia, K. Mioduski, M. Siewierski, Kodeks karny: komentarz [Criminal Code: Commentary], Vol. 2, Wydawnictwo Prawnicze, 1987, p. 85. 
was used by the perpetrator, for "is it more cruel than, for example, killing with an axe or a knife".

Following the amendment changes introduced by the Act of 26 November 2010 (Journal of Laws of 2010, No 240, item 1602), homicide committed with a firearm was removed from the qualified types. It seems that, quite unusually, the legislature responded to the critical voices of doctrine, which considered it controversial to include murder with a firearm as a qualified type. Justifiably, the qualified type of murder with the use of explosives was retained.

Not only does Polish law distinguish between the basic, qualified, and privileged types of homicide. Other legislation and legal systems also distinguish between the basic, qualified, and privileged types.

The Anglo-American common law system distinguishes between murder (qualified type) and manslaughter (ordinary or privileged type). In order for a homicide to be classified as murder, it must be committed with so-called premeditation, i.e. it must be planned. ${ }^{6}$ German law distinguishes between simple homicide and qualified murder. Murder with a firearm is included in the ordinary type. In French law, the distinction between the qualified type (murder) and the ordinary type is based on the malicious or planned manner in which it is committed. A number of legislations (e.g. Swedish or Austrian) do not distinguish between qualified types of homicide. ${ }^{7}$

Suicide represents a major social problem. In the Polish legal system no punishment is imposed for suicide, only for incitement to commit it (Article 151 of the Penal Code). It is similar in most legal systems in the world. Until recently suicide was punishable (incompetently, of course) in Canada (until 1973). In England, suicide ceased to be a crime as late as 1961, when the "Suicide Act" was passed. Since then, as in the rest of the world, aiding and abetting has been punished. The Dutch Penal Code

5 A. Marek, Prawo karne w pytaniach i odpowiedziach [Criminal Law in Questions and Answers], TNOiK, 2001, p. 245; see also K. Daszkiewicz, "Ciężkie zabójstwo [Severe Homicide]", Monitor Prawniczy, 1997, Issue 12, p. 483.

${ }^{6}$ A. Marek, Prawo karne [Criminal Law], Wydawnictwo CH Beck, 2011, p. 425.

7 Ibid., p. 425. 
pays particular attention to the provision of the means by which the act of attempting suicide by the aided person may take place. ${ }^{8}$

\section{THE IMPACT OF FIREARMS AVAILABILITY ON HOMICIDE RATES}

In Poland, between 2002 and 2020, 698 homicides were committed with firearms out of a total of 12752 homicides, accounting for only $5.5 \%$ of homicides. ${ }^{9}$ This fact was also pointed out by M. Całkiewicz, who examined 130 criminal case files concerning homicides. In only 5 cases (less than $4 \%$ ), did the perpetrator use a firearm. ${ }^{10}$ It is worth noting that in the police statistics, in addition to homicides committed with actual firearms, homicides with gas weapons are also listed. In a period of 19 years this occurred only 6 times! In the total number of homicides with firearms, this is only a fraction of a percent $-0.05 \%$ of the number of homicides with firearms. M. Całkiewicz, cited above, writes that the most common tool used by the perpetrators was a knife (66 cases), but also a locksmith's hammer, an axe or a fork. ${ }^{11}$

For reference, it is useful to see the ratio of overall homicides to those committed with firearms in other countries.

The highest number of homicides by means of firearms is recorded in South American countries. ${ }^{12}$ According to the World Health Organization (WHO), in Venezuela alone in 2014 there were 8,194 homicides with firearms (approximately 27 homicides with firearms per 100,000 inhabitants) out of a total of 19,030 homicides. This represented more

${ }^{8}$ B. Hołyst, "Samobójstwo - przypadek czy konieczność” [Suicide - an Incident or a Necessity], Państwowe Wydawnictwo Naukowe, 1983, p. 118.

9 Source - Przestępstwa przy użyciu broni - Broń - przestępstwa - Statystyka (policja.pl), [last accessed 9.07.2021].

${ }_{10}$ M. Całkiewicz, Modus operandi sprawców zabójstw [The Modus Operandi of Homicide Perpetrators], Publ. Poltext, 2010, p. 142.

${ }^{11}$ Ibid., p. 142.

${ }^{12}$ More broadly L. Stępka, Dostęp do broni palnej w Ameryce Południowej a zabójstwa z jej użyciem [Access to Firearms in South America and Homicide by Firearms], in E. Gruza (ed.), Oblicza wspótczesnej kryminalistyki. Księga jubileuszowa profesora Huberta Kołeckiego [The Faces of Contemporary Criminalistics. Professor Hubert Kołecki's Jubilee Book], Stowarzyszenie Absolwentów Prawa UW, 2013, pp. 255-265. 
than $43 \%$ of all homicides. In the same year in Colombia, there were 9,152 homicides with firearms (approximately 20.6 cases per 100,000 inhabitants) out of a total of 12,057 homicides, and this represented as much as $76 \%$ of all homicides. ${ }^{13}$ By contrast, in Brazil, which has one of the most liberal firearms laws, the majority of homicides are committed with firearms - over $74.5 \%{ }^{14}$ In all South American countries it is necessary to have a firearms licence to own a firearm. Unfortunately, a large proportion of homicides with firearms in these countries is the work of gangs and, above all, drug cartels. The situation is similar in Mexico, where the right to possess firearms is guaranteed by constitutional provisions with restrictions imposed by law. ${ }^{15}$ There too, the criminal activities of drug cartels and gangs have a very significant impact on the increase in homicides involving firearms.

Also in the United States of America, where legal firearms are easiest to obtain, in 2019, of the total number of homicides, $76 \%$ were committed with a firearm! ${ }^{16} \mathrm{~J}$. Stukan writes that in mass killings the most common tool was the firearm. ${ }^{17}$ According to this author, perpetrators choose it because it has the greatest power of destruction. In the 47 cases of mass killings studied by J. Stukan, mainly from the USA, firearms were used in 34 of them. ${ }^{18}$

From 2002 to 2019, a total of 314,376 homicides were committed in the USA. This means, approximately 5.64 homicides per 100,000 population. Of these, 195,002 or $62.03 \%$ of all homicides were committed using firearms. The most frequently used weapons were pistols and re-

${ }^{13}$ WHO 2021, 'Inter-country Comparison of Mortality for Selected Causes of Death.' WHO Mortality Data Base. Geneva: World Health Organisation. 9 July.

14 Brazil. 2021 'Mortalidade - 1996 a 2017, pela CID-10 [Mortality - 1996 until 2017, according to ICD-10].' DATASUS [Unified Health System Database]. Brasilia: Ministry of Health. 9 July.

${ }^{15}$ P. J. Cook, W. Cukier, K. Krause, "Firearms and Firearm Regulation in North America": Mexico", The Illicit Firearms Trade in North America: Criminology \& Criminal Justice, 2009, Vol. 9, Issue 3, p. 271.

${ }^{16}$ CDC. 2021 'Underlying Cause of Death, Results.' CDC WONDER Online Database. Atlanta, GA: Centers for Disease Control and Prevention / CDC, National Center for Health Statistics. 9 July.

17 J. Stukan, Masowi mordercy [Mass Murderers], Publ. Prometeusz, 2009, p. 38.

18 Ibid., p. 38. 
volvers - 122.047 cases. ${ }^{19}$ During the same period, as mentioned earlier, 12,752 homicides were committed in Poland. Firearms were used in a total of only 698 instances. Of course, it should be remembered that there are over 300 million people living in the United States and only 38 million in Poland, but the number of homicides per 100000 inhabitants is more than double that in Poland. The most important thing, however, is that the majority of them in the USA are committed with a firearm. American statistics also distinguish between what is known as justifiable homicide, for the purpose of protecting the law (actions by the police and other services). In the period in question (2002-2019), 7,464 people were justifiably deprived of their lives by services acting to protect the public, using firearms. ${ }^{20}$ The Polish police do not keep such precise statistics: the only information given is the number of times police officers legitimately used their weapons - amounting to 164 times between the years 2013 and 2020. ${ }^{21}$ Whether and how many individuals were shot is unknown, but it should be remembered that this is the total number of shots fired (including warning shots).

Advocates of expanding the availability of firearms to the public argue that more firearms in the hands of citizens does not translate into the number of homicides committed with them. The examples cited from Venezuela, Columbia, Brazil, and the United States seem to contradict this.

Data released by Gunpolicy.org 22 also reveal that in the Czech Republic and Switzerland, where gun laws are liberal, more homicides are committed with firearms than in Poland, the UK, and Australia, where there is strict regulation of access to firearms.

It is also worth noting that in just one city, Milwaukee, Wisconsin, in the four years between 2004 and 2008, a total of 489 homicides occurred, $77 \%$ of which were committed with a firearm. ${ }^{23}$ In a city the

19 CDC.2021, supra note 16.

${ }^{20}$ Ibid.

${ }^{21}$ Source - http://www.statystyka.policja.pl/portal/st/999/51797/Użycie_broni_ sluzbowej_przez_policjantow.html, [last accessed 31.08.2012].

${ }^{22}$ Compare the Czech Republic - Rate of Gun Homicide per 100,000 People (gunpolicy.org) - [last accessed 9.07.2021].

${ }^{23}$ S. G. Brandl, M. S. Stroshine, "The Relationship Between Gun and Gun Buyer Characteristics and Firearm Time-to-Crime", Criminal Justice Policy Review, 2011, Vol. 22, Issue 3, p. 286. 
size of Wrocław (population of approximately 600 000), in 2005 there were 94 homicides with firearms! ${ }^{24}$ The State of Wisconsin belongs to the group where firearms are relatively easy to obtain. In order to buy one, one has to be at least 18 years old (in the case of pistols) or 21 (in the case of revolvers). It is also necessary to wait 48 hours from purchase to receipt of the gun (the time it takes to verify that the person wishing to buy the gun has no criminal record). As firearms are often bought on the spur of the moment, these two days are intended to tone down any possible emotions in the prospective owner. There is no limit on the number of times a person may purchase a small firearm..$^{25}$ According to a study by S. G. Brandl and M. S. Stroshine in Milwaukee, firearms are most commonly purchased by African American or Hispanic males (82.1\%), aged about 30 years. In most cases, these are medium-calibre $(9 \mathrm{~mm}, .380, .357, .32, .38)$ self-reloading firearms. The researchers wanted to see how much time elapsed between obtaining and using the weapon during a crime. Only weapons seized by police from captured criminals were examined. These are most often weapons acquired illegally from a backstreet dealer. Their research shows that weapons were used during the commission of a crime usually after a period of more than 3 years. ${ }^{26}$ The authors propose, in order to curb the illegal firearms market, that the police check suspicious vehicles (under the pretext of a road check), and perform controlled purchases from illegal sellers. ${ }^{27}$ Finally, the authors draw attention to the social cost of shootings. In Milwaukee, the cost of treating a gunshot victim is an average of $\$ 38,000$. Most victims do not have insurance, thus medical costs are spread across all citizens. The annual medical costs of gunshot victims is estimated to be over $\$ 100$ billion across the United States!

There can be absolutely no doubt that a high firearms saturation rate also results in a large number of murders and suicides involving firearms. This can be proved by comparing the United States, Switzerland, and Finland, where firearms are common, with the United Kingdom or Poland, where the availability of firearms is strictly regulated. In the United States, more than 10 fatal incidents involving firearms occur per

\footnotetext{
${ }^{24}$ Ibid.

25 Ibid., p. 290.

${ }^{26}$ Ibid., p. 294.

${ }^{27}$ Ibid.
} 
100,000 inhabitants. Most victims are male ( 8.7 per 100,000 inhabitants) ${ }^{28}$ Only slightly fewer of such incidents are recorded in Switzerland, at around 7 per 100000 inhabitants. In contrast, less than 1 fatal gun incident is recorded in the United Kingdom or Poland. ${ }^{29}$ It should be noted, however, that fatal incidents involving firearms in Switzerland are mainly suicides, which constitute a major problem in Switzerland.

It is also worth noting the use of a firearm under the influence of alcohol against a sexual partner e.g. spouse (wife), partner (partner). D. W. Roberts conducted extensive research related to this problem and came to the conclusion that, unfortunately, the easy availability of firearms results in frequent murders of closest partners when the perpetrator is under the influence of alcohol. ${ }^{30}$ The author analysed data from 1985-2004. D. W. Roberts states, following Jensen, that where the perpetrator is a woman, in $30 \%$ of cases the victim is the closest life partner. ${ }^{31}$ Women, unlike men, were more likely to use a knife rather than a firearm to kill their partner. ${ }^{32}$ Interestingly, homicides of sexual partners were most common in the summer and in southern and western states, where firearms saturation is highest. Also, killings of sexual partners were more common in rural than in urban areas. ${ }^{33}$ In the twenty years that were studied by this author, in the USA 46,784 sexual partner homicides took place, of which 26,498 involved firearms (57\%). Homicides often occurred under the influence of alcohol. ${ }^{34}$

Well-known American criminologists and victimologists L. Hepburn and D. Hemenway stated in their study that "where there are more guns, there are more murders". ${ }^{35}$ It is difficult to disagree with such a statement, especially since it is supported by criminological research. D. Hemenway and M. Miller arrived at the same conclusion after ana-

${ }^{28}$ D. W. Roberts, "Intimate Partner Homicide. Relationships to Alcohol and Firearms", Journal of Contemporary Criminal Justice, 2009, Vol. 25, Issue 1, p. 67.

29 A. Edwards, J. Sheptycki, "Third Wave criminology. Guns, crime and social order", Criminology E Criminal Justice, 2009, Vol. 9, Issue 3, s. 388.

${ }^{30}$ D. W. Roberts, supra note 28, p. 67-88.

${ }^{31}$ Ibid., p. 67.

32 See ibid., p. 70.

${ }^{33}$ Ibid., p. 71.

${ }^{34}$ Ibid., p. 77.

${ }^{35}$ L. Hepburn, D. Hemenway, "Firearm availability and homicide: A review of the literature", Aggression and Violent Behavior, 2004, Vol. 9, Issue 4, pp. 417-440. 
lyzing data from 26 countries. ${ }^{36}$ The same researchers also concluded that states with more guns also have more homicides. ${ }^{37}$ These conclusions contradict the claim, evident in some discussions, that the more weapons there are, the less crime occurs because criminals are afraid to commit crimes for fear of losing their own lives. Just as the death penalty does not deter people from carrying out homicidal acts once they have chosen to do so, so the increased availability of weapons will not reduce crime.

In Canada, gun laws changed radically in 1995. As recently as 1991, $25 \%$ of households had guns, while in 2003 they were in only $18 \%$ of homes. ${ }^{38}$ Usually these are hunting weapons, as Canada has a strong hunting tradition. After the change in the gun law, no increase in crime was observed, no increase in homicides and suicides. On the contrary, there has been a regression in both homicides and suicides by firearms. ${ }^{39}$ It is noticeable that there has been a very large decrease in the number of robbery offences in the period since 1995. In 1981, an average of 38 robberies with firearms per 100,000 inhabitants were recorded, while in 2007 only 11 such crimes per 100,000 inhabitants. ${ }^{40}$ This shows that the introduction of the regulated availability of firearms has had a positive impact on the reduction of crime involving firearms, particularly violent crime such as robbery and homicide. For example, there were 15 times as many homicides involving short firearms in the United States as in Canada ${ }^{41}$ and this only after 2-3 years following the introduction of a law restricting the availability of firearms to civilians.

${ }^{36}$ D. Hemenway, M. Miller, "Firearm availability and homicide rates across 26 high income countries", Journal of Trauma-Injury Infection \& Critical Care, 2000, Vol. 49, Issue 6, pp. 985-988.

37 M. Miller, D. Hemenway, D. Azrael, "State-level homicide victimization rates in the US in relation to survey measures of household firearm ownership 2001-2003", Soc. Sci. Med., 2007, Vol. 64, Issue 3, pp. 656-664.

38 P. J. Cook, W. Cukier, K. Krause, "The illicit firearms trade in North America”, Criminology \& Criminal Justice, 2009, Vol. 9, Issue 3, p. 270.

39 J. Sheptycki, "Guns, crime and social order. A Canadian perspective", Criminology E Criminal Justice, 2009, Vol. 9, Issue 3, pp. 307-336.

${ }^{40}$ Ibid., p. 322.

${ }^{41}$ W. Cukier, "Firearms Regulation: Canada in the International Context", Chronic Diseases in Canada, 1998, Vol. 19, Issue 1, p. 27. 
W. Cukier, in his paper, provides an interesting analysis of how the availability of firearms to civilians affects the level of firearms crime, including the one most affecting society, which is homicide. The data provided by the author indicate that countries where guns are widely available had the highest number of gun homicides. For example, in the USA, where $41 \%$ of households have firearms, 62.4 homicides per million inhabitants were reported, while in Japan, where possession of firearms for personal protection is prohibited and only $0.6 \%$ of households have firearms, only 0.3 homicides per million inhabitants were recorded.

Similarly, in Australia, since the availability of firearms to citizens has been restricted, the number of homicides involving firearms has fallen dramatically. In 1991, there were 629 recorded firearm homicides, while in 2001 the number of such cases had fallen to $333 .{ }^{42}$

US researchers found a strong correlation between firearm availability and firearm homicide rates. ${ }^{43}$

Criminologists and forensic scientists are not the only researchers to study the impact of firearm availability on firearm homicide rates. Mathematicians at the University of California at Irvine have made a mathematical analysis of how the availability of firearms affects the rate of homicide by firearms. It is very clear from the findings of these mathematicians that easier access to firearms increases the rate of homicide by firearms. ${ }^{44}$

\section{IMPACT Of Firearms AVAILABILITY on SUICIDE RATES}

The question must be addressed as to whether a large number of weapons also means an increased number of suicides using them. As one can guess, suicide by firearm will certainly be more effective than

${ }^{42}$ Data from the Australian Institute of Criminology, [after:] S. Wright, "Gun death halved in past 10 years", The Age of 3 January 2004, p. 8.

${ }^{43}$ M. Siegel, C. S. Ross, C. King, "The Relationship Between Gun Ownership and Firearm Homicide Rates in the United States, 1981-2010", American Journal of Public Health, 2013, Vol. 103, Issue 11, pp. 2098-2105.

${ }^{44}$ D. Wodarz, N. L. Komarova, "Dependence of the Firearm-Related Homicide Rate on Gun Availability: A Mathematical Analysis", PLOS 1, 2013, Vol. 8, Issue 7, pp. 1-13. 
by other means that are supposed to be painless such as swallowing poison, a drug overdose, etc. Of course, equally effective, if not more so, will be suicide in the form of jumping from a great height, or drowning after attaching a heavy weight to one's legs, but this requires some effort. One has to find a high enough building (or go to the mountains), try to get a boat and a weight. Shooting a gun, on the other hand, is simple, all it takes is pointing the barrel in the right direction and pulling the trigger.

The world literature is replete with facts showing that the increased availability of firearms increases suicide rates. As mentioned above, Switzerland, where guns are in $36 \%$ of households, is facing this problem. ${ }^{45}$ On average, 57.4 suicides are committed by firearms per million inhabitants in this mountainous country. ${ }^{46}$ Between 1998 and 2007, 13410 suicides were recorded in Switzerland, of which 3169 (23.6\%) were committed by firearms. ${ }^{47}$

Another good example of how a large number of firearms negatively affects the number of suicides with firearms is Finland. This northern European country is one of the countries with the highest firearms saturation (even higher than the USA). Firearms are in the possession of $50 \%$ of households. It is true that most of these will be hunting weapons, but this does not change the fact that every second Finnish household does have one. The number of firearms in Finland is also reflected in the number of suicides with firearms. According to W. Sugar, there are 57.8 such incidents per year per million inhabitants in Finland! ${ }^{48}$

However, the highest number of suicides by firearms is recorded in the United States, with 72.3 such incidents per year per million inhabitants!

At the other extreme is Japan, with its strict regulation of firearms and 0.36 suicides per million inhabitants. ${ }^{49}$ Also low levels of suicides by firearms are recorded in the Netherlands $(2.8$ per million inhabit-

\footnotetext{
45 A. Edwards, J. Sheptycki, supra note 29, p. 388.

${ }^{46}$ W. Cukier, supra note 41, p. 27.

${ }^{47}$ V. Ajdacic-Gross et all, "Firearm suicides and availability of firearms: The Swiss experience", European Psychiatry, 2010, Vol. 25, Issue 7, pp. 432-434.

${ }^{48}$ Ibid.

${ }^{49}$ Ibid.
} 
ants), Great Britain (3.3 per million inhabitants), and Spain (5.5 per million inhabitants). ${ }^{50}$

It is worth noting how suicide rates have changed following the introduction of firearms rationing. A good example is Australia, where access to firearms for individuals was radically restricted in 1996. In 1983, the suicide rate in that country was 11.6 per 100,000 inhabitants per year. Firearms were used in $29.5 \%$ of cases. Also in 1993 , firearms were used in $18.6 \%$ of suicides. After the change in the gun law, there was a marked decrease in the number of suicides committed with firearms. And so in 2000, only $10.2 \%$ of suicides involved a firearm. ${ }^{51}$ Between 1997 and 2004 there was a decrease of $7.1 \%$ in the number of suicides committed with firearms. In 2004 an average of 1.7 suicides were committed in this way per 100,000 inhabitants. ${ }^{52}$ Unfortunately, the change in the gun law did not contribute radically to the decline in the total number of suicides. The suicide rate ranges from 14.69 in 1997 to 12.99 in 2019 per 100,000 inhabitants. ${ }^{53}$ There is no clear drop in suicide rates in Australia following the restriction of access to firearms.

Another example of a country where the number of suicides by firearms has fallen dramatically, following restrictions placed on their availability, is Canada. In 2000, $19 \%$ of suicides in this large country involved firearms, whereas, before the change in the law, in 1993, as many as $28.2 \%$ of suicides were committed with firearms. Canada has also decreased the suicide rate per 100,000 inhabitants. In 1992, it was 13.19, and in 2018 it dropped to $10.30 .^{54}$ There was a clear decrease in the total num-

50 Ibid.

51 V. Ajdacic-Gross et all, "Changing times: A Longitudinal Analysis of International Firearm Suicide Data", American Journal of Public-Health, 2006, Vol. 96, Issue 10, p. 1753.

${ }^{52}$ H. Klieve, M. Barnes, D. De Leo, "Controlling firearms use in Australia: has the 1996 gun law reform produced the decrease in rates of suicide with this method?", Soc. Psychiatry Psychiatr. Epidemiol., 2009, Vol. 44, Issue 4, pp. 285-292.

53 Australia. 2020 'Underlying Cause of Death, All Causes, Australia, 2010-2019.' Causes of Death, Australia, 2019; 3303.0 (Table 1.2). Canberra: Australian Bureau of Statistics. 23 September.

54 Canada. 2021 'Deaths and Age-Specific Mortality Rates, by Selected Grouped Causes.' Data. Ottawa ON: Statistics Canada. 10 September. 
ber of suicides. In 2003, it was 8.25 per 100,000 inhabitants, but in 2018 it fell to 5.77 cases per 100,000 inhabitants. ${ }^{55}$

Another good example of the decline in suicides after restricting access to firearms is Israel. There, a $40 \%$ drop in suicides by firearms was recorded only after soldiers serving in the Israeli army were banned from taking their weapons home with them at weekends. ${ }^{56}$

In general, researchers believe that reducing the availability of firearms results in a reduction in suicide. For example, Harvard University professors M. Miller and C. W. Barber, and E. Betz from the University of Colorado come to the conclusion that introducing restrictions on access to firearms is an anti-suicide measure. ${ }^{57} \mathrm{~A}$ similar opinion is also expressed by D. Hemenway, S. Lippmann, and D. Azrael. ${ }^{58}$ H. S. Szlyk, E. Azasu, and S. Joe in their article also believe that restricting the availability of firearms contributes to reducing the rate of suicide by firearms. These researchers report that as many as $85 \%$ of all suicides in the US are committed with firearms. ${ }^{59}$

Of interest is the action taken after the highly publicized mass shooting in Colombine in 1999, to take guns away from a person who could potentially commit suicide. Connecticut became the first state to pass a law allowing the police to temporarily take away a person's gun when there is "probable cause to believe ... that the person poses a risk of imminent injury to himself or others". ${ }^{60} \mathrm{~J} . \mathrm{W}$. Swanson and a team of

${ }^{55}$ WHO. 2021 'Inter-country Comparison of Mortality for Selected Causes of Death.' WHO Mortality Data Base. Geneva: World Health Organisation. 10 September.

${ }^{56}$ G. Lubin et al., "Decrease in Suicide Rates After a Change of Policy Reducing Access to Firearms in Adolescents: A Naturalistic Epidemiological Study", Suicide and Life-Threatening Behavior, 2010, Vol. 40, Issue 5, pp. 421-424.

57 See M. E. Betz, C. W. Barber, M. Miller, "Firearm restriction as suicide prevention: variation in belief and practice among providers in an urban emergency department", Injury Prevention, 2010, Vol. 16, Issue 4, pp. 278-280.

${ }_{58}$ M. Miller, S. Lippmann, D. Azrael, D. Hemenway, "Household firearm ownership and rates of suicide across the 50 United States", Journal of Trauma-Injury Infection $\mathcal{E}$ Critical Care, 2007, Vol. 62, no 4, pp. 1029-1035; G. M. Zimmerman, E. E. Fridel, “Contextualizing Homicide-Suicide: Examining How Ecological Gun Availability Affects Homicide-Suicide at Multiple Levels of Analysis", Homicide Studies, 2020, Vol. 24, Issue 2, pp. 151-177.

${ }^{59}$ H. S. Szlyk, E. Azasu, S. Joe, “Firearm Suicide as a Human Rights Priority for Prevention", Journal of Law \& Policy, 2019, Vol. 60, Issue 133, pp. 134-136.

${ }^{60}$ CONN. GEN. STAT. § 29-38c (1999). 
researchers have found that a law allowing preventive firearms revocation has had an effect on reducing the suicide rate in the state. Indeed, the preventive removal of firearms contributes to a moderate reduction in suicide by firearm. ${ }^{61}$ The researchers determined that the moderate decline in firearm suicides is related to the difficulty of establishing whether a potentially dangerous person owns a firearm. In the USA, the researchers found, there are more guns than people, and the trade in them does not always take place through official sales channels. Many guns are purchased at fairs and through private advertisements. ${ }^{62}$

Another interesting study was conducted by J. Kappelman and R. C. Fording. They examined the impact of legislation on firearm suicide among young people from 1981 to 2017. Based on their research, they concluded that restricting access to guns for young people by appropriate legislation contributes to a reduction in the rate of firearm suicide among children and youth. ${ }^{63}$

In Poland, suicides are relatively rarely committed with firearms, despite the fact that Poland unfortunately belongs to countries with a high suicide rate. In 2020 the level oscillated around 10 suicides per year per 100.000 inhabitants. ${ }^{64}$ Police data show that between 2000 and 2020, 115,814 suicides were committed, but only 1,195 using firearms (about $1 \%$ of all suicides) ${ }^{65}$ It was very rare for women to commit suicide by firearm - only 18 female suicide victims (between 2000 and 2016) chose to take their own lives using a firearm. ${ }^{66}$ In the police statistics there is no information on what type of firearms were used during a suicide. This data only confirms that in countries where the availability of firearms is low, suicides rarely use firearms.

${ }^{61}$ J. W. Swanson et al., "Implementation and Effectiveness of Connecticut's RiskBased Gun Removal Law: Does it Prevent Suicides?", Law and Contemporary Problems, 2017, Vol. 80, no 179, p. 208.

${ }^{62}$ Ibid., pp. 206-208.

63 J. Kappelman, R. C. Folding, "The effect of state gun laws on youth suicide by firearm: 1981- 2017", Suicide Life Threat Behav., 2021, Vol. 51, pp. 368-377.

${ }^{64}$ Source - Zamachy samobójcze - Statystyka (policja.pl), [last accessed 14.07.2021].

${ }^{65}$ Ibid.

${ }^{66}$ WHO. 2021 'Inter-country Comparison of Mortality for Selected Causes of Death.' WHO Mortality Data Base. Geneva: World Health Organisation. 14 July. 


\section{CONCLUSION}

The article shows that facilitated access to firearms has an impact on homicide and suicide rates with firearms. Even small changes in the law that make access to firearms more difficult have a real impact on reducing homicide and suicide by firearms. The examples of Australia, Canada, and the UK, where the availability of firearms to individuals has been drastically reduced, show that limiting the availability of firearms has been instrumental in reducing homicide and suicide by firearms. A review of the world literature clearly demonstrates a strong correlation between the availability of firearms and homicide or suicide by firearms. 
